\title{
XLII. Studies of the ultra-violet transparency of certain coloured media
}

\section{H.W.L. Absalom B.Sc. A.R.C.S.}

To cite this article: H.W.L. Absalom B.Sc. A.R.C.S. (1917) XLII. Studies of the ultra-violet transparency of certain coloured media , Philosophical Magazine Series 6, 33:197, 450-455, DOI: $10.1080 / 14786440508635657$

To link to this article: http://dx.doi.org/10.1080/14786440508635657

册 Published online: 08 Apr 2009.

Submit your article to this journal $[\pi$

Џ Article views: 2

Q View related articles $\asymp$ 


\begin{tabular}{|c|c|c|c|}
\hline $\begin{array}{c}\text { T'omp. } \\
\circ \mathrm{C} .\end{array}$ & $\begin{array}{c}\text { Compressibilty, } \\
\beta \times 106, \\
\text { at from } 50-100 \text { atmos. }\end{array}$ & $\begin{array}{c}(\nabla-b), \\
\text { in c.c. }\end{array}$ & $\begin{array}{c}\pi, \\
\text { in atmos. }\end{array}$ \\
\hline 0 & 133 & $2 \cdot 98$ & 7520 \\
20 & 158 & $3 \cdot 79$ & 6400 \\
40 & 203 & $5 \cdot 25$ & 4940 \\
60 & 252 & $6 \cdot 89$ & 3970 \\
80 & 315 & $9 \cdot 13$ & 3180 \\
100 & 395 & $12 \cdot 00$ & 2540 \\
\hline
\end{tabular}

magnitude of a few thousand atmospheres; whilst, as should also be the case, the values for the free space are relatively small as compared with the volumes of the molecules themselves.

XLII. Studies of the Ultra-violet Transparency of Certain Coloured Media. By II. W. L. Absalom, B.Sc., A.R.C.S." $7 \mathrm{TE}$ present investigation originated in an attempt to 1 find some colouring matter which, while opaque in the yellow region of the spectrum, should transmit as far as possible into the ultra-violet. Such a material would be of great use in developing certain investigations on the fluorescence of sodium vapour which have been made in this laboratory (see Strutt, Proc. Roy. Soc. Nov. 1915).

With this object a number of little-known colouring matters were examined, and the subject was afterwards pursued for points of interest it was found to possess in itself.

The coloured metallic salts and the aniline dyes have already been well explored (see Uhler and Wood, "Atlas of Absorption Spectra'), but fow of them possess much altraviolet trausparency. Attention was turned therefore to the blue rock-salt of Stassfurt, believed to owe its colour to colloidal sodium. This was found to be very transparent, and the observation led on to investigation of other naturally coloured minerals and precious stones as well as to various preparations of colloidal metals, such as the solutions of alkali motals in anhydrous liquid ammonia.

\section{Gems and Minerals.}

The arc between copper poles was employed as the source of radiation. By means of a small quartz spectrograph, photographs were obtained of the portion of the spectrum between $\lambda 5000$ and $\lambda 2250$. The specimen under exami-

- Communicated by the Author. 
nation was fixed with wax over a small hole in a screen of sheet ebonite, in such a way that no radiation could reach the slit of the spectrograph save after transmission through the specimen. In the case of a cut stone care was taken that it was orientated so that the light had the best chance of transmission, and in minerals where the distribution of colour was irregular the convergent radiation was in general directed so as to traverse the part of deepest colour. Several exposures of varying duration were made with each specimen, the maxima ranging from ten to thirty minutes according to the nature of the specimen.

In the following table the wave-lengths denote the point at which complete absorption commences.

1. Natural blue rock-salt. ............... Beyond 2250

2. Natural rock-salt coloured by cathode rays.. Beyond 2250

3. Sylvite, white.$\ldots \ldots \ldots \ldots \ldots \ldots \ldots$. Beyond 2250

4. Ditto, coloured blue by cathode rays ...... Beyond 2250

5. Chili saltpetre, ordinary white variety ......... 3512

6. Ditto, violet $\ldots \ldots \ldots \ldots \ldots \ldots \ldots \ldots \ldots \ldots \ldots \ldots \ldots \ldots \ldots \ldots$

$\left.\begin{array}{l}\text { 7. Fluorspar, coloured deep viulet by cathode } \\ \text { rays } \ldots \ldots \ldots \ldots \ldots \ldots \ldots \ldots \ldots \ldots \ldots\end{array}\right\}$ l3eyond 2250

8. Diamond, yelluw ........................ 3200

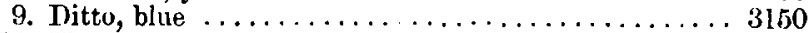

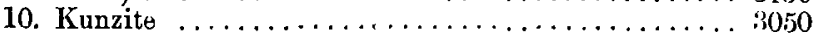

11. Garnet, red ....................... $40 \pm 2$

12. Zircon (hyacinth) red-brown $\ldots \ldots \ldots \ldots \ldots \ldots .2618$

13. Ditto, decolorized by hent.................. 2442

14. Ditto, green. . . . . . . . . . . . . . . . . . . . 4023

15. Ditto, yelluw ........................... 4023

16. Topaz, pale yollnw.. . ................... 2618

17. Ditto, dark yellow ........................ 2294

18. Ditto, pale pink-brown . . . . . . . . . . . . . . 2618

19. Ditto, blue $\ldots \ldots \ldots \ldots \ldots \ldots \ldots \ldots \ldots \ldots . . \ldots 2961$

20. Emerald $\ldots \ldots \ldots \ldots \ldots \ldots \ldots \ldots \ldots \ldots \ldots \ldots, 3200$

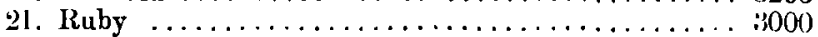

22 . Tourmaline, green ....................... 3512

23. Ditto, green-yellow $\ldots \ldots \ldots \ldots \ldots \ldots \ldots \ldots \ldots . . \ldots 00$

24. Ditto, pink ....................... 3064

25. Spinel, blue . . . . . . . . . . . . . . . . . . . . 402;

26. Ditto, purple $\ldots \ldots \ldots \ldots \ldots \ldots \ldots \ldots \ldots \ldots, 3248$

27. Ditto, pink ........................ 3000

28. Kyanite, blue ........................ $3: 00$

29. Beryl, blue ........................ $325 \bar{\tau} 4$

30. Cordierite, blute-purple . . .................... 3248

31. Cairngorm ......................... 3248

Notes on the above:-

1. This is the natural blue rock-salt of Stassturt. It is said to be found at the boundary of the salt with some of the potash minerals.

2. Ordinary white rock-salt coloured a deep blue by cathode-ray bombardment. This has always been considered kindred to the natural blue salt, and is now seen to behave 
like it in this respect also. The colour is, however, superficial instead of being diffused through the mass.

6 . This pale violet variety of Chili saltpetre, occurring naturally, can be decolorized by heat, like the blue rocksalt. The colour may then be restored by cathode-ray bombardment. The same colour can be in some measure imparted to a piece of the ordinary white Chili saltpetre by bombardment, but in this case the coloration is not uniform but banded, suggesting that its development depends on some impurity.

7. The specimen was originally greenish in colour, but the violet colour imparted by bombardment was very much deeper.

\section{Solutions of Metals in Liquid Ammonia.}

It has been known for some years that the metals sodium, potassium, lithium, rubidium, csesium, barium, strontium (and magnesium to a less extent), react with liquid ammonia, producing fine blue colorations. The blue colour is not permanent; its duration varies with the metal and with the purity and dryness of the metal and the ammonia. It is believed that the metal dissolves in the ammonia forming the blue colloidal solution, and that then a reaction occurs resulting in the formation of an amide with the liberation of hydrogen-the disappearance of the colour marking the final conversion of the metal in solution into anide. The stability of solutions increases in the order potassium, calcium, lithium, sodium. Considerable attention has been devoted to the reaction which takes place and to the physicochemical properties of the solutions. (Moissan, Comptes Rendus, 1898; Krauss, J. Am. (hem. Soc. 1907, 1908, 1914.)

Recently Argo and Gibson (Phys. Rev. Feb. 1916) have studied the absorption of the blue solutions of sodium, potassium, and magnesium by means of the spectro-photometer. There appears to be no record of observations carried out in the ultra-violet region.

In the present instance attempts were made initially to obtain the blue solutions of sodium in liquid ammonia. Some 880 solution of liquid anmonia was heated and the gaseous ammonia led through a long tube packed with soda-lime, and thence by a very thin drawn-out tube into a silica tube surrounded by a freezing-mixture of solid carbon dioxide and methylated spirits. When sufficient liquid ammonia had collected, a small piece of sodium, as free as possible from oxide and moisture, was introduced and the silica tube then sealed off. As soon as the tube was removed from the freezing-mixture the metal seemed to swell somewhat, and the contents of the tube soon assumed a deep blue clotted appearance. Similar results were obtained with potassium 
and calcium. In all cases the colour persisted but for a few days, and sometimes disappeared very rapidly if only a small piece of the metal had been used. A white precipitate remained. The almost opiaque nature of the contents of the tube rendered the photography of absorption spectra difficult. By supporting the tube horizontally and rotating steadily it was hoped to obtain a sufficiently transparent and uniform film, lut the liquid did not

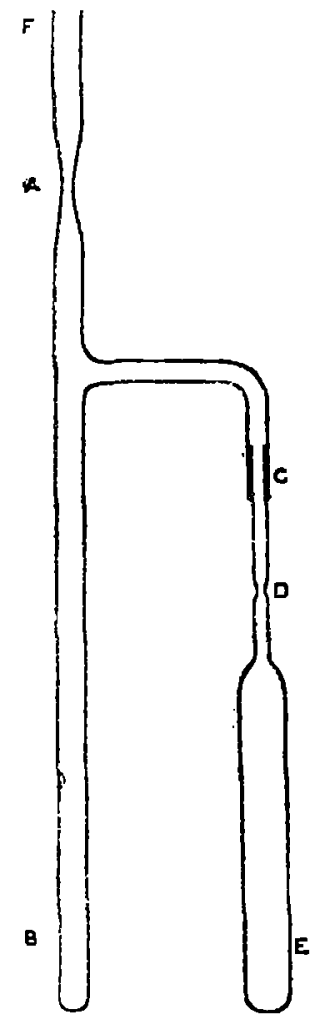
adbere sufficiently well to the walls of the tube. Ultimately attempts to obtain photographs were made as the blue colour became less dense. The tube was fitted tightly into a deep cork. A hole at right angles to the former allowed light to traverse the liquid. The results with a calcium solution were the most satisfactory, but even these were not altogrether consistent.

More recently solutions of magnesium have been obtained by Cottrell (J. Phys. Chem. 1914.) He found that with freshly scraped motal and dry ammonia blue solutions resulted which were of considerable permanence, persisting in one case for several years.

The apparatus in the present case is shown.

$\mathrm{CE}$ was of silica, the remainder of glass. A tew small pieces of freshly scraped magnesium ribbon were introduced into $E$, which had been previously cleaned and dried. A constriction was made at $D$ and the silica tube then joined to the glass by means of a sealing-wax joint at $C$. $F$ was connected to a Gaede pump, and when the pressure was very low $\mathrm{E}$ was heated to disengage any gases. (Cottrell, ibid.) The purnp was then disconnected, $B$ immersed in liquid air and ammonia collected as a solid in the way described above. A fow pieces of sodium were dropped into $B$ to account for any water which may have passed over with the ammonia. The pump was again connected and the tube sealed off at $A$. B was removed from the liquid air, and when the ammonia had liquefied $\mathrm{E}$ was inmorsed in the liquid air and the ammonia distilled over. The liquid contents of $E$ were afterwards washed back into $B$, and then distilled over to E again. The silica was soaled off

Phil. Mag. S. 6. Vol. 33. No. 197. May 1917. 2 I 


\section{Ultra-violet Transparency of Certain Coloured Media.}

at $D$. The blue colour appeared within a few hours, and with one solution has lasted to the time of writing-nearly three months.

A piece of black paper was wrapped round the tube and pasted along a narrow strip. In it were made two small holes diametrically opposite. The diameter of the tube was $1 \cdot 5-2 \mathrm{~cm}$., so that the light was incident practically normally at one hole, and it was impossible for light from the arc to reach the spectrograph without having traversed the solution.

Exposures varying from 10-600 seconds were made with both pale and deep blue solutions, and in all cases total absorption commenced at $\lambda 2442$. The limit of transmission for liquid ammonia is $\lambda 2393$. (In the earlier experiments with calcium absorption seemed to commence at $\lambda 2618$.

Hence the blue solutions transmit for a considerable distance into the ultra-violet, but they could not be used for screening purposes in that-sided cells on account of the high vapourpressure of ammonia at ordinary temperatures. Solutions in the primary amines which have higher boiling-points would be more suitable.

Lithium and cosium dissolve in methyl-amine (boilingpoint $-6^{\circ} \mathrm{C}$.), lithium dissolves in ethyl-amine $\left(19^{\circ} \mathrm{C}.\right)$. (Moissan, Comptes Rendus, 1899 ; Rengade, ibid. 1905.) Solutions in the higher primary amines have not been obtained.

Attempts to prepare solutions of lithium and magnesium in ethyl-amine by the above method proved unsuccessful, probably because the ethyl-amine was not properly dry.

Experiments have also been made on a solution of colloidal gold (after Furaday). When freshly prepared the limit of transmission was $\lambda 2492$. After a day had elapsed it had moved to $\lambda 2767$.

\section{Discussion of Results.}

One general result is that transparency far into the ultraviolet is much more commonly met with in the case of colour due to colloidal metals than it has been found to be in ordinary coloured salts or aniline dyes. This is clearly illustrated by the natural blue rock-salt and the various salts and minerals coloured by cathode rays. We cannot, of course, expect to find ultra-violet transparency in the coloured substance unless it was present before coloration. Thus the violet Chili saltpetre is opaque in the ultra-violet light, but this opacity is equally met with in white samples: on the other hand, where the uncoloured substance is transparent, coloration in the visible region by bombardment leaves this unaffected.

The nature of the colouring matter in gems is in many cases 
undetermined, nothing appearing in the analyses to account for it. It was thought that colloidal metals might in some cases be concerned; and if ultra-violet transparency were found, this would be considerable evidence for such a view. It bas been found that the variety of zircon called hyacinth only begins to be opaque at $\lambda 2617$, and one variety of yellow topaz at $\lambda 2294$. In these cases the presumption is strong that the colouring matter is of the nature of a colloidal metal.

The extreme ultra-violet transparency of the solution of magnesium in ammonia confirms the view that these metallic solntions are to be regarled as colloidal.

The author desires to acknowledge his gratitude to Professor the Hon. R. J. Strutt, F.R S., for suggesting the work, and for continuous interest and advice.

Physics Department, Iumperial College of Science and Technology, S.W.

XLIII. Proceedings of Learned Societies.
GEological socierT.
[Continued from p. 296.]
January 24th, 1917. - Dr. Alfred Harker, F.R.S., President,
in the Chair.

Mr. Scoresiy Routzeden, M.A., gave an aceount of Easter Island. He said that the Expedition, that he had had the honour to command, was organized with the object of carrying out a long-standing wish of various bodies interested in anthropology. This wish was that Easter Island, and other islands most near to it, though far distant from it, should be thoroughly examined, and that all information and material thereon found should be carefully considered on the spot, or, if possible, be brought back for comparative study.

This programme necessitated a vessel being specially designed, built, and equipped for the purpose. A schooner with auxiliary motor power, the 'Mana,' of 90 tons gross register, 78 feet on the water-line, 20 feet beam, and drawing 10.5 feet aft, was accordingly completed by the end of 1912, and she sailed from Southampton in February 1913 with a company of twelve all told, of whom four formed the scientific staff. After the longest voyage ever made by a yacht under canvas, she sailed into Southampton again in June 1916, without having experienced accident to man or material.

The conrse taken was through the Magellan Straits, and thence through the labyrinth of Andean waterways that stretch north therefrom, and are known as the Patagonian Channels.

On reaching Juan Fernandez Island, the 'Mana' had to put back to Valparaiso because the geologist of the Expedition, the late Mr. F. L. Corry, had contracted typhoid fever on the Chilean coast. Mr. Corry never recovered sufficiently to allow him to 